\title{
The Swedish Tar Company : Balancing Between Privileges, Commerce and Foreign Politics
}

\section{Tikka, Katja}

Brill

2020-09-01

Tikka, K 2020 , The Swedish Tar Company : Balancing Between Privileges, Commerce and Foreign Politics . in The Development of Commercial Law in Sweden and Finland (Early pÿModern Period Nineteenth Century) . Legal History Library, no. 40 , Brill, Leiden, pp. 92-125 . https://doi.org/10.1163/9789004436046_005

http://hdl.handle.net/10138/337164

https://doi.org/10.1163/9789004436046_005

unspecified

acceptedVersion

Downloaded from Helda, University of Helsinki institutional repository.

This is an electronic reprint of the original article.

This reprint may differ from the original in pagination and typographic detail.

Please cite the original version. 


\title{
The Swedish Tar Company - Balancing Between Privileges, Commerce and Foreign Politics
}

\author{
Katja Tikka \\ University of Helsinki
}

\section{Introduction}

The peace treaties of Westphalia were finally signed between Sweden, France, Spain, the Netherlands and The Holy Roman Empire in 1648. Thereafter, Sweden gained a leading position in the Baltics and Scandinavia in terms of both politics and geography. ${ }^{1}$ These novel circumstances expanded the commercial interests of Sweden, which meant a new era for commercial legislation. In the same year, the first Swedish tar company was founded in Stockholm. The Crown granted the company a privilege to export tar and pitch from the north of the country, which covered the whole of Finland and the greater Stockholm area. The right to export tar was in practice a monopoly; single merchants were afterwards barred from trading in $\operatorname{tar}^{2}$

This chapter ${ }^{3}$ studies the tar company as a corporation selling one specific article - tar - and its processed product, pitch: items desired by the trading powers of Europe. Meanwhile, Sweden had extensively begun to practise the government-based ideology of mercantilism as the guiding principle of the economy. Furthermore, the company was capturing the mind of the monarch. ${ }^{4}$ Nevertheless, the tar company failed to connect these two contradictory tendencies. The purpose of this chapter is to explain the management of the company, how it related to earlier Swedish companies, and whether any parts of the legislation regarding the company may

\footnotetext{
${ }^{1}$ For more see David Kirby, Northern Europe in the Early Modern Period; The Baltic World 1492-1772 (London: Longman, 1990), 123 and 171-180. In the year 1630, Sweden participated in the European war, which started as a religious war between the Catholic Church and North German protestant princes. King Gustav II Adolphus intervened in North-west Germany with the consent of the Elector of Brandenburg. After the victory of Sweden in 1626, the war shifted to Polish Russia. Stralsund became Sweden's first permanent base in Germany in 1628. After that, control over the Eastern Baltic ports was strengthened and Livonia was conquered. Peace negotiations continued for years before the parties finally managed to approve the complex parts of the agreements in 1648 .

2 The original tar privilege "Privilegium för Tiäru Handels Compagniet" is printed in Anders Anton von Stiernman, Sweriges Rikes commerce. politie och oeconomie uti gemen uppå Hans Kongl.Maj:ts nodigsta belfallning, Andra delen. (Stockholm: Kong. trykeriet, 1750), 525-530; Annagreta Hallberg, "Tjärexport och tjärhandelskompanier" in (ed.) Steinby, Torsten Historiska och litteraturhistoriska studier no 34, (Helsinki: Svenska litteratursällskapet i Finland, 1959), 106.

${ }^{3}$ The Chapter is partly based on Tikka's doctoral dissertation, Shipping Legal Norms - Swedish Trading Companies in the Seventeenth century (Helsinki: Unigrafia, 2020).

${ }^{4}$ Jonathan Israel, Dutch Primacy in World Trade 1585-1740 (London: Clarendon Press, 1989), 222; Kirby, Northern

Europe in the Early Modern Period, 149. See also Dave De ruysscher's chapter p
} 
be referred to as a legal transplant. The chapter discusses the rules, privileges and statutes that affected the company. Within the framework of the project ${ }^{5}$ of Professor Heikki Pihlajamäki, some discussion has focused on company statutes. These often differ according to the branch of business. Moreover, the growing scale of businesses and the need for larger capital lent variety to the models. This chapter brings to the discourse a limited focus: only one sales article - tar - that brings a totally new aspect to this discourse. ${ }^{6}$

During the decades following establishment of the first Swedish tar company, several consecutive tar companies were founded, since the interests of the Swedish kings and merchants differed. The main intention of the Crown was to accrue financial capital by controlling prices and the amount of tar purchased from producers and sold to foreign traders. However, due to strict rules, the markets could not develop freely, and new legislation was introduced as the disadvantages came to light. This chapter surveys the background to the evolution of the tar companies' legal character in Sweden.

First and foremost, it is necessary to present a general overview of Swedish chartered companies before the tar companies. Swedish economic history has its own special character, influenced by both the country's northern location and the position of the estates, which differed from the Central European model. As a result, legal development also followed its own path. In addition, it should be noted that the structure of Swedish society had unique administrative characteristics during the seventeenth century. ${ }^{7}$

Before the tar company, a few nascent trading companies already existed in the 1610s. Dave De ruysscher's chapter in this book discusses the legal character of the first Swedish companies, which were influenced by the Dutch. ${ }^{8}$ Hence, I will not discuss the details of the earliest companies here. Instead, this chapter explains

\footnotetext{
${ }_{6}^{5}$ See a description of the project from the Introductory chapter, $\mathrm{p}$

${ }^{6}$ Bram van Hofstraeten, "Delving for Diversity in Early Modern Company Law: Mining Companies in SeventeenthCentury Liège", in (eds.) De ruysscher et al.: The Company in Law and Practice: Did Size Matter? (Middle AgesNineteenth Century) (Leiden: Brill, 2017), 107-108; Anja Amend-Traut, "Legal Structure of Early Enterprises - from Commenda-like Arrangements to Chartered Joint-Stock Companies", in (eds.) De ruysscher et al. The Company in Law and Practice: Did Size Matter? (Middle Ages-Nineteenth Century) (Leiden, Brill 2017), 81-83; Ella Gephen-Jager, Gerard van Soling and Levinus Timmerman (eds.), VOC 1602-2002, 400 Years of Company Law (Dordrecht: Kluwer, 2005), 75.

${ }^{7}$ Mirkka Lappalainen, "Loyal Servants of the King and the Crown (1620-1680) - Stewards and Governors in Sweden before the Age of Absolutism," in (eds.) Petri Karonen and Hakanen Marko, Personal Agency at the Swedish Age of Greatness 1560-1720 (Helsinki: The Finnish Literature Society (SKS), 2017), 131-132; Tikka, Shipping Legal Norms, see "Introduction".

${ }^{8}$ Kirby, Northern Europe in the Early Modern Period, 149; Kaarle Wirta, Dark Horses of Business, Overseas Entrepreneurship in seventeenth-Century Nordic Trade in the Indian and Atlantic Oceans (Leiden University, 2018), 30-32.
} 
the importance of the tar trade to Sweden and Europe, and answers the essential question as to who buyers, producers and traders were, and what kind of motives each side represents.

The main sources of this study consist of original documents in the Riksarkivet in Stockholm. The focus of earlier research has not been the operations of the company or its legal character or at least hardly at all. Therefore, fundamental research at a basic level is needed. Karl Oskar Fyhrvall's 1880 dissertation, Bidrag till Swenska handelslagstiftingens historia is the oldest known analysis of Swedish company law, and especially that relating to tar companies ${ }^{9}$. However, the primary approach in his research is narrative-based, without deeper analysis. For example, Fyhrvall claims that the development of tar companies had a negative effect on the national spirit of Sweden. The main reason for this lay in the company model, which easily led to illegalities. Moreover, Fyhrvall wrote his dissertation over 130 years ago, so his conclusions are partly outdated. The next - and broader - analysis of the tar company is Annagreta Hallberg's chapter Tjärexport och tjärhandelskompanier under stormaktstiden. ${ }^{10}$ This research from 1959 represents aspects of the company's trading. Hallberg sees the tar companies as an example of a new business model in early modern Europe. Her focus is the tar trade and how it moulded Sweden's international relations with the Netherlands and England.

As existing research on this topic does not take a strong legal approach, the original archive materials need to be critically investigated. This material includes the company's privileges, orders from the monarch, proposals by the Commercial Collegium, complaints to the King from the burghers and peasantry, decisions by the lower courts, and parliamentary proceedings. ${ }^{11}$ Most of these sources are in the Stockholm State Archive ${ }^{12}$ in the "Miscellanea" section, and the collection in the "Commerce and Seafaring" section, where all the archive materials of Swedish commercial companies can be found.

One of the main methods used in this chapter is comparison between the early stages of privilege and the situation vis-á-vis the later companies. The change in regulation reflects the progress of the trading companies,

\footnotetext{
${ }^{9}$ Ernst Gustaf Palmén’s study Historisk framställning af den svensk-finska handelslagstiftningen från Gustaf Vasas regering till 1766, (Helsinki: J. C. Frenckell \& Son, 1876) was published in 1876, but its perspective is not as deep as Fyhrvall's.

${ }^{10}$ Published in the book Historiska och litteraturhistorista studie, 34 (Helsinki, 1959).

${ }^{11}$ Moreover, in printed versions you can find statutes, privileges and sessions of the Swedish Parliament.

${ }^{12}$ In original called Riksarkivet.
} 
which later became modern institutions. Surrounding elements, such as war, economic innovations, and the varying balance between the estates, created economic booms and recessions. These had a wide effect on the tar companies' future development.

The tar companies exerted a particularly strong influence on Finland. ${ }^{13}$ For that reason, this chapter concentrates more on Finland than Sweden. Certainly legislation, regulations and administration concerning the companies were formulated in Stockholm, Sweden`s capital. Nonetheless, the consequences of the foundation of the company were seen at grass-roots level mainly in Finland.

The following paragraphs first explain the characteristic features of Swedish society as a culture that allowed local mercantilism to form its own shape and expression. The next paragraphs deal with the tar trade and clarify the situation before the first tar monopoly. Without a detailed introduction, the essence of the tar company and the problems it faced would be impossible to understand fully. In subsequent paragraphs, the lifespans of the three individual tar companies are then described. Finally, the chapter concludes by describing the monopolised tar trade as a logical narrative of the pre-modern chartered company.

\section{Mercantilism in Sweden}

During the seventeenth century, the whole of Europe faced extensive change. War raged across the continent, and the need for financial capital, iron, weapons and food supplies grew rapidly at the same time. There was thus a broad interest in importing the conditions for commerce, as the country that managed to create the most effective trading system would also succeed on the battlefield. This new commercial system was the target of huge expectations, with tar and pitch seen as products over which Sweden could also have a monopoly in European markets. ${ }^{14}$

Mercantilism was the ruling economic tendency in Europe from the sixteenth century onwards. Its commercial ideology focused on profit-seeking at a national level. The roots of the ideology were in the European mineral

\footnotetext{
${ }^{13}$ Finland was ruled by the Swedish Crown for nearly 700 years: from the 12 th century until 1809, when Finland became part of the Russian Empire.

${ }^{14}$ Thomas Lindkvist \& Maria Sjöberg, Det Svenska samhället 800-1720; Klerkernas och adelns tid (Lund: Studentlitteratur, 2010), 306-312; Peter Wolfgang Klein, “A New Look at an Old Subject: Dutch Trade Policies in the Age of Mercantilism", in (eds.) Simon Groenveld \& Michael Wintle, State and Trade, Government and the Economy in Britain and the Netherlands since the Middle Ages, (Zutphen: Walburg Press, 1992), 39.
} 
industry and bullion trade, which was seen as a key element for countries to gain national capital. Mercantilism was considered the guiding principle for building an economically strong and independent country. Mercantilism strove to maintain a positive foreign trade balance, keeping export prices high and import prices low. Sweden adopted mercantilist ideas in the sixteenth century, when foreign trade was influenced by north German cities. ${ }^{15}$

In the first half of the seventeenth century, Sweden became a northern superpower. The period 1630-1720 is also known as the age of greatness in Nordic historiography. King Gustav II Adolphus led successful battles and conquered the most fertile territories around the Baltic Sea. The huge "granaries" of the Baltic States and Northern Germany fed the Swedish army and helped them to gain military victories. Finally, the King also had extensive administrative power over the country. The first Swedish commercial companies were founded during a time when mercantilism and monopolies were fundamental ideas in all commercial decisions. These economic notions dominated this age of greatness. At that time, financial ideologies were mostly adopted from France and Germany. In the theories of the historian Peter Englund, mercantilism took root in Sweden during the 1630s and the administration saw mercantilism as the only way to maintain a balance in trade. In contrast, the Netherlands followed its own trade policy based on free trade. Instead, in Sweden this kind of independence was not possible. ${ }^{16}$

These ideological tendencies had a strong effect on commercial legislation, causing its development to follow the trends prevailing in various periods. Legislation in the cities was based on city privileges, including permission to trade. In the 1350s, a common city law, known as the law of Magnus Eriksson, took effect. Even though the law mostly served Stockholm merchants, it was also used in other cities. The law defined how cities should be ruled. However, besides this, local rules - imposed by the mayor and the magistrate - existed in every city. In these cities, city bailiffs enforced the law. At the same time, immigrants and foreigners have

\footnotetext{
${ }^{15}$ Klein,”A New Look at an Old Subject”, 47; Eli Heckscher, Merkantilismen, (Stockholm: P. A. Norstedt \& Söners Förlag, 1953), 348.

${ }^{16}$ Leif Runefelt, Hushållningens dygder. Affektlära, hushållningslära och ekonomiskt tankande under svensk stormaktstid. Stockholm studies in economic history, (Stockholm: Almqvist \& Wiksell International, 2001), 1 and 1517; Mirkka Lappalainen, Maailman painavin raha, kirjoituksia 1600-luvun Pohjolasta, (Helsinki: Werner Söderström Osakeyhtiö, 2006), 89-90.
} 
traditionally had a great impact in Swedish cities by bringing with them new influences. Nevertheless, old customs were challenged with the founding of the first commercial companies. ${ }^{17}$

One of the main tools for fulfilling the idea of mercantilism was the legally complex notion of privileges. Rulers awarded privileges as advantages to certain people they wanted to control. Granting and receiving a privilege connected the parties to the contract, with both gaining benefits that were more or less unique. ${ }^{18}$ Earlier, privileges were used as town privileges. However, when the first Swedish chartered companies were founded, privileges were adapted to a new field. The winner in this scenario was the nobility, as the lower estates could not even dream of receiving such privileges because of strict social hierarchy. In the ambitious theories of philosophers, privileges brought advantages to society as a whole. In reality, however, it was only the few that benefited. Having a privilege almost without exception included obligations. ${ }^{19}$ For instance, in its first years the tar company attempted to buy and export tar as a commission-based business. Shortly thereafter, it was found necessary to reformulate tar trade practices on a very different basis. The company's activities required far more than simply dealing in tar. For example, over time the company incurred obligations such as importing salt for the whole of southern Finland. ${ }^{20}$

\section{The Tar Trade and its Legal Characteristics before the Company Model}

Finnish forests have traditionally been called green gold. However, the material that the forests produced was in fact pitch black: black gold. The reasons for tar being so profitable were many. First of all, producing tar required little financial investment. Even economic recessions had minimal effect on production itself. Second,

\footnotetext{
${ }^{17}$ Mia Korpiola and Maija Ojala-Fulwood, "Controlling Immigrants in Sweden, ca. 1520-1620: Norms, Regulation, and Legal Practice” in (eds.) Anette Baumann, Alexander Jendorff \& Frank Theisen, Religion - Migration Integration. Studies on the Reciprocal Effects of Religiously Motivated Mobility in Pre-Modern Europe (Tübingen: Mohrsiebeck, 2019), 212-213; Anders Björnsson \& Lars Magnusson (eds), Jordpäron, Svensk ekonomihistorisk läsebok (Stockholm: Bokförlaget Atlantis, 2011), 44-50; C. J. Gardberg, "Kaupunkilaitos keskiajalla ja uuden ajan alussa" in (eds.) Gardberg, C. J. - Tommila, Päiviö - Endén, Rauno, Suomen kaupunkilaitoksen historia (Vantaa: Suomen kaupunkiliitto, 1981), 31-32.

${ }^{18}$ György Nováky, Handelskompanier och kompanihandel; Svenska Afrikakompaniet 1649-1663, En studie i feodal handel, (Uppsala: Acta Universitatis Upsaliensis, 1990), 42-43.

${ }^{19}$ Leos Müller, The Merchant Houses of Stockholm, c. 1640-1800; A Comparatively Study of Early-Modern

Entrepreneurial Behaviour. (Uppsala: Uppsala University Library, 1998), 19.

${ }^{20}$ See for example "Placat om Tiäru och Beckhandelen 1654" Stiernman 1750, 781; Heikki Waris, Tervakauppakomppania vuosina 1648-1661. (University of Helsinki, approx. 1940), 39-43; Swen-Erik Åström, From Tar to Timber. Studies in Northeast European forest exploitation and foreign trade 1660-1860 (Helsinki: The Finnish Society of Sciences and Letters, 1988), 20.
} 
the Crown, which owned most of the forests in Finland, allowed the peasantry to make use of the forests without charge. Burning tar, with its many stages, took several years, but it cost only time and effort - not money or financial resources. ${ }^{21}$ Third, in Finland a large part of the country was covered by a network of lakes and rivers, which enabled transport of barrels of tar over great distances. During the sixteenth century, Sweden was almost constantly in a state of war. This required extra taxes from the peasants, and tar offered an additional source of tax revenue. ${ }^{22}$

During the sixteenth century, the leading tar-exporting port in Europe was situated in Danzig. The forests in Poland and Prussia had offered useful resources for tar production. However, by the 1620s suitable wood from those areas had apparently run out. At the same time, England and the Netherlands had become large-scale consumers of tar because of the burgeoning need for trading vessels. Tar was essential for sealing the wooden parts of vessels and strengthening the ropes. It also prevented rotting. ${ }^{23}$ The tar markets were thus wide open to Swedish merchants, and the Dutch also knew how to exploit the situation.

The economic circumstances prior to establishment of the tar companies meant that the export of tar was limited and followed a certain codification. The city tax was the main duty which merchants needed to pay, while customs and harbour duties were also mandatory, the payments being proportional to the volume of sales. The leading tar-exporting cities were the Finnish cities of Turku, Helsinki, Vyborg and the Swedish cities of Stockholm, Västervik and Kalmar. In those cities, the markets were often in the hands of the wealthiest families, who also held leading positions in the city. ${ }^{24}$ They bought tar barrels from peasants who had transported them to the city for sale. Primarily, the ideology of mercantilism affected the arrangement of

\footnotetext{
${ }^{21}$ Oiva Turpeinen, Mustan kullan maa; Tervan historia, (Somero: Amanita, 2010), 26-32.

${ }^{22}$ Katja Tikka, "Kauppaa ja laivoja, Komppaniatoiminnan kehityspiirteitä 1600-luvun Itämerellä" in (ed.) Tapio Bergholm, Työ merellä, Nautica Fennica 2015-2016 (Helsinki: Suomen merimuseo, 2016) 12-13; Seppo Aalto, Helsinki, tervakaupunki in (eds.) Jensen-Eriksen, Niklas, Lappalainen, Mirkka, Nurmiainen, Jouko and Siltala, Sakari, Kansallinen kapitalismi, kansainvälinen talous (Helsinki: Siltala, 2012), 50.

${ }^{23}$ Mia Korpiola, "High and Late Medieval Scandinavia, Codified Vernacular Law and Learned Legal Influences" in (eds.) Heikki Pihlajamäki, Markus Dubber, Mark Godfrey, The Oxford Handbook of European Legal History (Oxford: Oxford University Press, 2018), 289-290; Markku Kuisma, Metsäteollisuuden maa; Suomi, metsät ja kansainvälinen järjestelmä 1620-1920. (Helsinki: Suomalaisen kirjallisuuden seura, 2006), 27-29 and 35.

${ }^{24}$ Hallberg, Tjärexport och tjärhandelskompanier, 172. David Kirby \& Merja-Liisa Hinkkanen, The Baltic and the North Seas. Seas in History-serie. (London - New York: Routledge, 2000), 144-148.
} 
foreign trade, the idea being that concentrating on foreign trade in a few cities would offer the best opportunities. This initiative was introduced in 1614, during the era of King Gustav II Adolphus. ${ }^{25}$

Swedish society and in particular the field of commerce underwent drastic changes following the 1614 initiative. Before mercantilism, trade had been controlled differently. Local farmers with small sailing vessels had conducted a significant portion of foreign trade outside cities. This kind of modest trade was so common that the Crown began to consider it ineffective. After 1614, only two Finnish cities possessed staple rights, i.e. the right to engage in foreign trade. The new regulation directly affected the tar trade, doubling it in one year. Three years later, the regulation was expanded to two other Finnish cities, Porvoo and Helsinki, which were also granted staple rights. Disputes between merchants were resolved in the cities at two levels. Lower court sessions were held in market places, while higher court rulings were delivered in the magistrates' court in city halls. ${ }^{26}$ Thus commenced the golden age of exporting tar. In 1620 and 1622, all the tar exported to Western Europe was transported via Stockholm.

Not long afterwards, Vyborg became the most active tar city among the Finnish ports, and the tar trade continued to grow. ${ }^{27}$ In 1636, a new commercial regulation was introduced prohibiting foreign ships from sailing north of the latitude of Stockholm and Turku. It also ordered those two cities to arrange regular twiceyearly open markets, each lasting two consecutive weeks. Foreign merchants were also allowed to attend these markets. The Swedish King was now capable of controlling commerce in general and collecting specific payments, such as tolls. Tar had become a significant item of international trade, and the kingdom had raised awareness and expectations

in that regards. ${ }^{28}$ pic. [Vyborg 1600, Katja Tikka]

\footnotetext{
${ }^{25}$ Sylvi Möller, Suomen tapulikaupunkien valtaporvaristo ja sen kaupankäyntimenetelmät 1600-luvun alkupuolella. Dissertation, University of Helsinki (Helsinki: 1954), 15-16.

${ }^{26}$ Heckscher, Eli. F, An Economic History of Sweden (Cambridge: Harvard University, 1954), 73; Raimo Ranta, Turun kaupungin historia 1600-1721, (Turku: 1975), 685; Müller, The Merchant Houses of Stockholm, c.1640-1800, 43-44; Björnsson \& Magnusson, Jordpäron, 44-45; See also "Privilegier för Koop-Hendels Compagniet", Stiernman (ed.) (Stockholm 1747), 663, 665-667.

${ }^{27}$ J. W. Ruuth and Aimo Halila, Viipurin kaupungin historia 1617-1710, (Helsinki: Torkkelin säätiö, 1974), 11 and 113; Waris, Tervakauppakomppania vuosina 1648-1661, 34.

${ }^{28}$ Möller, Suomen tapulikaupunkien valtaporvaristo ja sen kaupankäyntimenetelmät 1600-luvun alkupuolella, 18-19.
} 


\section{Background to the First Privilege}

Other countries became attracted by Sweden's treasure of tar. In particular, the Dutch and the English were involved in this rising and expanding field of commerce. Ultimately, the Netherlands, with its modern economic and commercial policy was more tempting to Sweden. As an indirect result, the Netherlands subsequently affected Sweden's domestic policy more strongly than any other foreign state at that time. ${ }^{29}$

Conscious development of the production and sale of tar began with Dutch consultation. In 1629 Swedish nobleman and the commissary of Dutch commerce Konrad Falkenberg wrote to Sweden regarding local Dutch trade circumstances. This became the first known official mention of the tar trade. The commissary advised the Swedish Government to give careful consideration to adopting trade arrangements copied from the Dutch, as this would lead to greater profits. ${ }^{30}$ Subsequently, the chancellor of Sweden recruited the Dutch merchant Johan van Swindern to investigate the production and quality of tar in southern Sweden. Van Swindern was also granted a privilege with his compatriot David Grunau to export tar from Sweden to the Netherlands. This privilege also included the obligation to teach local people proper methods for manufacturing tar. In March 1634, van Swindern applied, alone, for an exclusive privilege. Subsequently, van Swindern was the first to apply for a privilege for the first tar company. ${ }^{31}$

With the support of the Swedish government, van Swindern continued his successful businesses after 1634 . He enjoyed a de facto monopoly, which encouraged him to continue investing, and his privilege covered the areas of Älvsborg and Gothenburg. Moreover, the local peasantry were obliged to supply him with as many wood products as he needed. ${ }^{32}$ Although van Swindern was the target of envy, the government stood behind him. This inspired van Swindern to request a monopoly that would cover the whole of Sweden.

\footnotetext{
${ }^{29}$ Jonathan I. Israel, Dutch Primacy in World Trade 1585-1740, (Oxford: Clarendon Press, 1989), 48-52; Clas Theodor Odhner, Sveriges inre Historia under Drottning Christinas Förmyndare (Stockholm: P. A. Norstedt \& Söner, 1865), 79-80.

${ }^{30}$ Kaarle Wirta, Dark Horses of Business, 29-31; Hallberg, Tjärexport och tjärhandelskompanier, 161.

${ }^{31}$ Original Letter of the King 13.8.1629, Tjärukompaniet och Förnyade tjärukomp 1648-1672; Handelskompanier, Handel och sjöfart vol. 63, Riksarkivet Stockholm (henceforth RAS); Karl Oskar Fyhrvall, Svenska Handelslagstiftningens historia, Tjärhandelskompanierna (Stockholm: 1880), 42.

${ }^{32}$ Privilege dated 23.3.1634, Ämnessamlingar, Handel och sjöfart, no. 12, RAS.
} 
Van Swindern's request raised fierce debate, with the result that his application was rejected. Interestingly, however, it was in this context that a chartered company was mentioned for the first time. In his proposal, van Swindern explained that there would be no upper limit to the company's sales prices. This indicated that without large sales volumes, profit would stay low. He also explained that the monopoly would allow cooperation with Dutch merchants to remain well-organised and that, moreover, under his control the company model would also produce higher profits for Swedish merchants, who would no longer need to sell every single barrel by themselves. The Swedish Chancellor of State supported the idea of founding a company, but his justifications were different. In his view, the main rationale was the economic benefits to the peasantry. By contrast, opponents of the proposal argued for free markets and free trade. ${ }^{33}$

In addition, the Swedish army argued against the establishment of a company because of van Swindern's apparent personal obsession with the occasion. Many other comments centred on the sum of money which was needed to initiate the operations of the company. ${ }^{34}$ Among the protests, a clear concern for the peasantry nevertheless appeared. If the clerks of the company enjoyed excessive control, they might pressure the peasants to accept lower prices. ${ }^{35}$

Demand for Swedish tar rose considerably during the 1640s. Cooperation with the Netherlands stabilized, with changed political attitudes. At the same time, competition accelerated between England and the Netherlands over shipbuilding, in which tar played an important role. Van Swindern had fulfilled expectations. The Swedish ministers De la Gardie and Oxenstierna made a tour of inspection in Finland. After that it was clear to oblige van Swindern to improve the reduction of tar in the northern parts of the country as a counterpart in tar privilege. $^{36}$

Van Swindern began to fulfill these hopes impressively, and his business model closely approximated to that of the future company. ${ }^{37}$ The main tar-selling cities saw development of a certain group of merchants who

\footnotetext{
${ }^{33}$ Copy of original Council of Ministers protocol in Severin Bergh (ed.) Handlingar rörande Sveriges historia. Svenska riksrådets protokoll 1645, 1646, tredje serien, part XI. (Stockholm 1906), 149.

${ }^{34}$ Hallberg, Tjärexport och tjärhandelskompanier, 164.

${ }^{35}$ Protocoll of the Council of the realm part 11, 255 and part 12, 149. RAS.

${ }^{36}$ Ämnessamlingar, Handel och sjöfart, no. 12, Kammarkollegio, RAS.

${ }^{37}$ A letter from the King 5.8.1643, The National Archives of Finland, Helsinki, ('NAF'): "In every staple town there must be certain tar officers placed in a 'Tar court': A quality controller, a tar secretary, a tar lower and a cooper. These workers will serve the tar organization."
} 
focused on exporting tar. In 1643, some ten merchants sold $60-70 \%$ of exported tar. This was controlled by giving each merchant his own quota for the number of tar barrels which could be bought from the producers. This similarly guaranteed small traders

the chance to participate in the tar markets. ${ }^{38}$

\section{The First Norland Tar Company 1648 and its Privilege}

Finally, in March 1648 attitudes stabilized and the privilege application for the company was accepted by the Council of the realm of Sweden. ${ }^{39}$ Besides van Swindern, the founders of the Norland tar company were merchants Wolff, Liliencrantz and Westerman. In addition to van Swindern these three were respected and well known burghers in Stockholm. At the time of its establishment, around ten other merchants invested in the company. The company privilege was granted for the next twenty years. The privilege covered northern parts of Sweden, with its southern border drawn between Stockholm and Nyen. The main purpose of the privilege was to allow a certain group of reliable merchants to have the right to buy all the tar and pitch produced in the northern parts of Sweden. No one outside the company had permission to export tar. Likewise, all the tar produced had to be sold to the company. The sphere of operations covered Norland, Finland and Carelia. ${ }^{40}$

The tar privilege was the main legal text concerning the company. It contained nine paragraphs and was a licence to buy and export tar. The new regulation ordered those who previously had permission to export tar to sell their stocks to the new company. The privilege focused on certain details but did not cover the full extent of the company's operations. The purpose of the company was to assist in the selling of tar and pitch "in the most proper and state supporting way." ${ }^{41}$ It also specified the conditions, geographic latitudes and rights which delineated the scope of its operations. In the privilege, the prices of tar and the level of customs duties were precisely defined. In addition, the privilege determined the geographical area of tar production and the

\footnotetext{
${ }^{38}$ Waris, Tervakauppakomppania vuosina 1648-1661, 71-72.

${ }^{39}$ In Swedish "Riksråd", in Finnish "valtaneuvosto".

${ }^{40}$ Anders Anton von Stiernman (ed.), Samling utaf kongl. Bref, stadgar och forordningarr angaende Sweriges Rikes commerce, politie och oeconomie, vol. 2 (Stockholm 1750), 525-526.

${ }^{41}$ Privilegium för Tiäruhandels Compagniet in Stiernman (ed.) 1750, 527.
} 
maximum limit of output. The cities where the tar business could be conducted were Stockholm, Turku, Vyborg, Helsinki and Nyen ${ }^{42}$.

How could the company achieve its goals besides price control and its geographical monopoly? The privilege interfered with the operation of mayors and city councils, which were in a leading role. These organs were, due to the privilege, responsible for hiring officers to control the quality of tar and count all the barrels transported to cities. The measure used to count tar was a "läst" which comprised approximately 12 barrels of tar. In addition, customs duties were one of the main tools for the government to control operations. Customs officers were required to report annually to the highest tax authorities and the Swedish council chamber. The Finnish staple cities differed in this respect, because only certain coupons and payment orders were used. These were subsequently exchanged for cash in Stockholm. In fact, raising capital was the Swedish Crown's primary motive for the entire idea of the tar company. In the privilege, this matter drew much attention and was raised in several paragraphs. ${ }^{43}$

After the privilege was issued, the reaction in Finnish cities varied from displeasure to disbelief. The privilege did not only affect the tar trade, but it also changed trading habits in the northern areas of the Baltic Sea. Previously, merchants had freely bought tar from peasants and exported it to foreign merchants. In return, they imported necessary goods such as salt, spices and other items and traded them in the interior of the country. Suddenly, this traffic totally ceased. The ports became empty except for tar barrels, and the familiar partners of foreign merchants arriving to trade were unable to sell them anything. The largest reactions occurred in Vyborg. The economy of this eastern Finnish city was practically based on tar trading with north German cities. Now this trade was paralyzed, replaced by agents of the tar company. Local merchants were forced to sell their barrels to the company at almost the same price they had paid for them from the peasant producers. The controlled price markets were inflexible, and soon the Swedish government received cries of distress from the merchants and peasantry. ${ }^{44}$

\footnotetext{
${ }^{42}$ By contrast, the privilege emphasized that the tar produced south of Stockholm in the provinces of Wermeland, Dahl and Wästergöteland, had to be sold in Gothenburg. Moreover, tar produced in the provinces of Wästergöteland and in Småland and Halland had to be sold in Halmstad or Småland. Tar produced in the provinces of Kalmar, Wästervik or Gotland had to be sold in Visby ("Privilegium för tiäru handels comp 1648"), Stiernman 527.

${ }^{43}$ Stiernman, Privilegium för Tiäruhandels Compagniet, 528-530.

${ }_{44}^{4}$ Åström, From tar to Timber; Studies in Northeast European forest exploitation and foreign trade 1660-1860, 20; Tikka, Shipping Legal Norms, 149.
} 


\subsection{The Tar Privilege and Several Appeals}

The tar company provided several advantages to the Swedish Crown and the company's partners. The purchase prices of tar were low and negotiations between local merchants and the company were nonexistent. For the government, customs duties were easy to collect from just one actor: the company. Moreover, tar production was controllable, as the company was obliged to buy all the tar produced, and most importantly the monopoly maintained high sales prices to the English and Dutch. Intentions and hopes for the company were fulfilled as planned. As a result, the large number of complaints from Finnish merchants was not only undesired but also extremely irritating.

Initially, there was almost no compliance with the new ordinances. When an English merchant vessel sailed to Vyborg in the spring 1648, as it had for decades, the merchants of Vyborg sold tar to the English in the previous fashion. This recurred in the summer of the same year when a Dutch vessel appeared in the port of Vyborg. These offences earned strict reprimands from the Crown, but there were no further consequences. ${ }^{45}$ Soon after this, in 1649 , the first complaint about the actions of the company was sent to Stockholm. It was directed to the Crown and signed by every Finnish staple city. The reasons for the complaint were the same as earlier. Even so, the answer from the Queen was foreseeable: Foreign merchants were a serious threat to the Swedish tar trade and the monopoly was a necessary defence against the risk of them capturing the entire tar trade. ${ }^{46}$

Dissatisfaction continued, and at the beginning of 1650 the Queen received a significant written protest. This time, the Finnish cities were appealing for the right to trade independently. Moreover, the cities complained that their reputation among foreign merchants was ruined. Furthermore, low, non-negotiable sales prices were causing displeasure. Complaints continued to occur, and as a result, a special committee was sent to Vyborg to ascertain the actual conditions and circumstances in the city. These local investigations revealed that the local agents were serving their own interests rather than those of the company. For example, the company's first agent in Vyborg, Cröell, was caught paying too little to the merchants for barrels of tar. ${ }^{47}$

\footnotetext{
${ }^{45}$ Waris, Tervakauppakomppania vuosina 1648-1661, 72.

${ }^{46}$ Aalto, Sotakaupunki, 50-53 and 64-65.

${ }^{47}$ Appeal from the merchants of Helsinki, Tjärukompaniet och Förnyade tjärukomp 1648-1672, Handelskompanier, Handel och sjöfart vol. 63, RAS.
} 
The committee's report along with the complaints from the cities precipitated the next tar regulation, which was approved by Parliament on 23 November 1650. The regulation particularly concerned relations between Finnish and Norlandian cities and the company. Finally, after much frustrated criticism, the local merchants were granted some allowances. The most substantial change was permission to do business in Amsterdam, Lübeck, Hamburg and Danzig. The prerequisite for this business was nevertheless that the company received sufficient prior notice and that the merchants were in possession of a bill of exchange guaranteed by the city council or mayor. ${ }^{48}$

At the same time, Sweden had become a more stable superpower in the Baltic Sea area, which required reforms in the field of administration. The commercial, manufacturing and navigation sectors represented an important area for development. In 1651, the Commercial Collegium (Kommerskollegium) was granted unprecedented extra authority by the Crown. For the expanded Sweden, there was a need to be present and visible in its new provinces, and the College founded two new units in Wismar and Riga besides that of Stockholm. These new positions both strengthened and facilitated control. ${ }^{49}$ In the same year, England established its own version of the Council for Trade, which was closely connected with the Navigation Act. ${ }^{50}$

Nevertheless, complaints against the company still continued to appear, despite or because of the government's reaction to them. The affairs of the tar company were handled during a parliamentary session in 1654, when the tar company was clearly the main target of blame for difficulties with Vyborg merchants. After the dismissal of Cröell, Mechever and Hans Schmidt, who also tended to pursue their own private business interests, held the post of company agents. Moreover, van Swindern himself was dismissed from the company for dishonesty. ${ }^{51}$ For the next parliamentary session, the Finnish staple cities carefully prepared a new complaint, where they again applied for the right to export tar by themselves. The reasons were manifold. Firstly, Vyborg was facing an unforeseen problem: the city and its province was suffering from a shortage of

\footnotetext{
${ }^{48}$ Stiernman, Privilegium för tiäru compagniet 1649, 608-610.

${ }^{49}$ Stiernman 1750, Instruction för Commercie Collegium 1651, 670.

${ }^{50}$ Heikki Pihlajamäki, "The Birth of Commercial law in Early Modern Sweden” in (eds.) Heikki Pihlajamäki, Albrecht Cordes, Serge Dauchy, Understanding the Sources of Early Modern and Modern Commercial Law: Courts, Statutes, Contracts, and Legal Scholarship (Leiden: Brill, 2018), 274-276; Jonathan Israel, The Dutch Republic, Its Rise, Greatness and Fall 1477-1806 (Oxford: Clarendon Press, 1995), 55-56.

${ }^{51}$ See for example 31.1.1651 and 19.3.1653 dated resolution of parliament, Tjärukompaniet och Förnyade tjärukomp 1648-1672, Handelskompanier, Handel och sjöfart vol. 63, RAS.
} 
salt because Vyborg merchants could no longer trade with foreign merchants. Secondly, the sales prices of tar had declined in Europe, which lowered profits. Thirdly, the company made payments in copper coins, even though customs duties needed to be paid in silver coins. Fourthly, the company granted bills with limited validity, even though merchants could not know in advance when they would need to use them. This increased the practical difficulties of trade. However, the ultimate provocation came when the company's officials failed to appear in local courts to respond to these claims. ${ }^{52}$

As a result of all these complaints and the report of the Committee, ${ }^{53}$ a new commercial code for the tar trade was passed in August 1654. This allocated a certain number of shares to Finnish merchants in addition to Stockholmers, which transpired to be the most essential change in the new code. Thus these less affluent merchants finally had a possibility to be part of the hated tar company. The combined value of the shares in question was 30000 silver coins. The share issue was valid from the end of October 1654, and cities who redeemed shares had the right to a representative on the company's board of directors. It was underlined that both profits and losses would be divided equally among old and new shareholders according to the number of shares in their possession. ${ }^{54}$ This brought the company's character closer to that of the joint stock companymodel, because the position of the partners was recognized and specified for the first time.

In the commercial code of 1654 , a few other matters were also determined. New permanent prices were set, and the size of a barrel of tar was specified. The company was also ordered to import salt and other necessary sales items to Finnish staple cities. To facilitate smoother trading, the company was ordered to offer credit. In practice, however, trade with foreign vessels in staple

cities remained fully in the tar company's hands..$^{55}$

\subsection{Later Development and Dissolution of the First Company}

\footnotetext{
${ }^{52}$ Complaint from Vyborg 12.5.1654. Ämnessamlingar, Handel och sjöfart, no. 12, Kammarkollegio, RAS.

53 The report included interviews with citizens and the partners and heads of the Company. These were conducted by sending members of the trade commission to Vyborg. During these interviews, Vyborg merchants tried to convince the committee members to set aside half of the Company's shares for Finnish merchants. Stiernman, Placat om tiäru och beckhandelen 1654, 778-780.

${ }^{54}$ Stiernman, Placat om tiäru och beckhandelen 1654, 778-780.

${ }^{55}$ Stiernman, Placat om tiäru och beckhandelen 1654, 780-782.
} 
The year 1654 was notable for Sweden in an economic and political sense. In that same year Queen Christina abdicated and was succeeded by her cousin Carl X Gustav in June. During the reign of Christina, the Swedish economy had suffered a recession. Her methods of governance had proven fatal, and the newly crowned King faced severe challenges. At the same time, during 1652-1654 the first Anglo-Dutch war was in progress, which negatively affected the Swedish tar trade. ${ }^{56}$ In 1654 , Parliament decided to grant greater authority to the Commercial Collegium. This meant that citizens of staple cities could no longer directly complain to the Crown about commercial matters. Rather, they could only direct their complaints to the Commercial Collegium, whose task was to consider cases individually and decide whether thereafter to present complaints to the King. Local disputes were directed to the local courts for resolution. The new commercial tar code precipitated an enormous leap in legal consciousness. The dispute process began primarily with the local courts, and after that, the next level was the Commercial Collegium, which decided whether to introduce the case to the monarch. ${ }^{57}$

Despite the reforms of 1654 , the tar company nevertheless continued to face adversity. The political atmosphere in Sweden was fractious, and attitudes towards King Carl X Gustav were contradictory. During his reign, the country was in a nearly constant state of war, which devoured state capital. ${ }^{58}$ Soon after, opinion became polarized towards the tar company. This occurred following the sudden death of the King during a parliamentary session in January 1660. His son, who was still under age, could not accede to the throne; instead, the Royal Regency assumed political power. The Regency was strongly against the existence of the tar company and began to advocate the company's dissolution, which provoked heated debate. ${ }^{59}$

Above all, practical difficulties concerning trade still remained. As the Dutch and English were the tar company's main partners, the discussions had to acknowledge the situation of the partners. Company agent Appelbom, who was on duty in the Netherlands, was obliged to negotiate with local merchants about the conditions of dissolution. The Dutch offered to donate 200000 silver coins to cover the company's debts, but

\footnotetext{
${ }^{56}$ Peter Englund, Det hotade huset: Adliga föreställningar om samhället under stormaktstiden, (Stockholm 1994), 206208.

${ }^{57}$ Anders Anton von Stiernman (ed.), "Placat om tiäru och beckhandelen 1654" in Samling utaf Kong. Bref, Stadgar och förordningar ungående Sweriges Rikes commerce, politie och oeconomie, vol. 3, (Stockholm: Tryckeriet, 1753), 782.

${ }^{58}$ Kirby, Northern Europe in the Early Modern Period; The Baltic World 1492-1772, 217-219.

${ }^{59}$ Parliamentary speech in Gothenburg, spring 1660, Riksregistraturet, RAS; Hallberg, Tjärexport och tjärhandelskompanier, 114 .
} 
the negations failed to progress further. ${ }^{60} \mathrm{~A}$ second practical problem was the high volume of tar production. In 1659, the Commercial Collegium had already received a memorandum from the company's director, Krister Bonde, expressing his concern about high tar production. During that time, the code obliged the company to buy all the tar produced, which caused uncontrollable difficulties. ${ }^{61}$

The first agreement on the dissolution of the company was passed in a parliamentary session in November $1660 .{ }^{62}$ Sweden's need for foreign credit had increased to unsustainable levels and required a rapid solution. Because the Anglo-Dutch war had practically frozen the tar trade, the government of Sweden was desperate. In February 1661, the Commercial Collegium issued a report which saved the company from dissolution at the eleventh hour. The College suggested that instead of closing down its operations, the tar company should be founded all over again, based on fairer principles. Moreover, it would have a wider-ranging investor base. A new five-paragraph statute for a reformed company was issued on 5 July $1661 .{ }^{63}$

The main reason for not dissolving the company completely was that the interests of the opposing parties were at such variance that refunding the tar company represented a provisional compromise. At a time of war, Sweden needed financial capital and a consensus had to be reached. Tar was seen as a trade product that could save the country. However, the complaints against the company were hindering the Commercial Collegium's efforts to further the interests of Sweden. The concerns of the Government and private citizens were nevertheless clearly at odds, which created a 'laboratory' where legal issues were evaluated. It must also be taken into consideration that the tar privilege was personally granted by the Crown. When the ruler passed away, the privilege automatically expired and it had to be concluded again with the following ruler. Therefore the death of the ruler precipitated decisions.

The main problem with the previous tar privilege was its overly superficial and general definitions. The essential purpose of the privilege was to promote the tar trade "in the most useful way". However, achieving this target was not anticipated beforehand in detail. The controlling of the prices was the practical way to guide the trade. Soon envy arose between the parties. Monopolies are generally seen as unfair and arbitrary entities,

\footnotetext{
${ }^{60}$ Parliamentary speech in Gothenburg, spring 1660, Riksregistraturet, RAS.

${ }^{61}$ Hallberg, Tjärexport och tjärhandelskompanier, 112-113.

${ }^{62}$ Stiernman, Riksdagarnas och mötens beslut II, 26.11.1660, 1396.

${ }^{63}$ Stiernman, Förordning om nya Tiäru-Compagniet 1661, 42-47.
} 
which was no exception even in this case. This case was no exception. Especially in Finland, the company and its directors were viewed as arrogant and elitist - to be fair, a not unreasonable view as only a few of the wealthiest merchants enjoyed the profits. Thus, it was a natural step for the Government to move the regulation of tar in a more practical direction.

\section{The Reformed Norland Tar Company and Its New Regulations From 1661 Onwards}

As noted, in 1660 the King of Sweden, Carl X Gustav, died suddenly during a Parliamentary session. The dissolution of the tar company and the founding of a new entity was partly the result of these events. In the same year, following the death of the King, Sweden signed a peace treaty with Russia. The treaty ceded parts of Poland to Sweden, and a temporary period of peace was attained. This allowed Sweden to pay greater attention to developing the country, and improvements in the field of law were also achieved. The new tar statute introduced essential reforms for Finnish cities at the expense of the company's directors. The changes focused on the trade and production of tar, and the statute's text concentrated on practical instructions.

During the summer of 1661 , a novel statute for the company was negotiated and passed. At the same time, to distinguish itself from the former company, the new entity was named the "reformed company" ${ }^{44}$ The updated statute intervened strongly in the ownership of the company. Concentration of ownership among a few of the wealthiest merchants was no longer permitted. Instead, strict limits on the level of share ownership were specified: a maximum of 1000 dalers and a minimum of 100 dalers ${ }^{65}$. Previous stakeholders had a preemptive right to redeem the shares. This control of investment powerfully affected the company's activities and its entire future, as the previous owners were forced to relinquish some of their shares. The shares also featured a novel method of resale. Finally, the new rules intentionally allowed the burghers of small tar cities to participate in the company. ${ }^{66}$

\footnotetext{
${ }^{64}$ Fyhrvall, Svenska Handelslagstiftningens historia, 54-55.

65 The Swedish monetary units were a complicated system in the early modern period. The old system based on marks, but was replaced first by copper coins and later silver dalers. Because the value of copper varied lot, it affected the value of money as well. The daler was originally worth of 28 grams of pure silver, but soon reduced to 26 grams. It was mostly used as a calculation unit and not as a practical coin. Möller, Suomen tapulikaupunkien valtaporvaristo, appendix 1.

${ }^{66}$ Stiernman 1753, Förordnung om nya Tiäru-Compagniet 1661, 43-47.
} 
Nevertheless, the novel regulations within the statute failed to overcome the company's difficulties. For instance, thousands of tons of tar had remained unsold by the previous company. One of the conditions of the reformed privilege was that all stockpiled tar was to be transferred to the new company. Moreover, the new legislation ordered the company to redeem all existing barrels of tar owned by city merchants. This was a demanding order to implement, as the majority of the company's capital was tied up in its tar. Luckily, the payment was over the long term, but on the other hand world market prices of tar decreased ${ }^{67}$

The main paragraphs of the new statutes were clearly generous compared to the previous ordinance, and smallscale local merchants in provincial Finnish cities really were taken into account. The paragraphs of the statute were also focused on controlling the amount of production. First, the company had the sole privilege to manufacture pitch from tar. This was explained by the fact that only the company knew the real consumption of pitch. Secondly, overproduction was a clear problem. Consequently, the statute also emphasized concerns about the country's forests and the possibility of their over-exploitation, which was seen as a threat to the entire nation. The end of the statute featured an order regarding the procedure for handling disagreements between the tar company and the cities. Complaints were to be primarily resolved with the help of the Commercial Collegium. ${ }^{68}$

The resolution of 1654 had solved the main difficulties of local burghers in the staple cities, and thus formed the basis of the statute of 1661. The Regency had a strong urge to improve Sweden's economy, and while the statute was not perfect, nevertheless it was the best that could be devised at the time.

pic. [1654 tar priv. Katja Tikka]

\subsection{The Reformed Tar Company at the Centre of Conflict}

The reformed tar company nevertheless soon faced adversity, as the company and the Royal Regency were headed for deadlock. The Regency insisted that company should receive more tar than it was capable of reselling. In addition, the Regency even defined the prices that the company was to pay for barrels of tar.

\footnotetext{
${ }^{67}$ Stiernman, Samling utaf Kong. Bref, Stadgar och förordningar ungående Sweriges Rikes commerce, politie och oeconomie, vol 3, 160-161.

${ }^{68}$ Stiernman 1753, Förordnung om nya Tï̈ru-Compagniet 1661, 46-47.
} 
Earlier, this had not been a problem because the prices in other countries were high. However, the situation had changed radically. During its first year, the reformed company was obliged to buy 23000 mers of tar, which was the largest amount the company had ever redeemed. This imposed an enormous burden on the management of the company's finances. In addition, the former partners meanwhile demanded redemption of their shares, while simultaneously Sweden's financial affairs were also worsening. ${ }^{69}$

At the beginning of 1662 , the directors of the tar company had already formulated a complaint concerning three matters: overly high customs duties, poor practices in dealing with bills, and the fact that tar production was exceeding consumption. The Regency responded on 21 March 1662. The only matter on which the Regency acquiesced was the lowering of customs duties: these were reduced retroactively from 1661. Instead, when it came to granting bills, an even stricter policy was launched. The Regency had become aware that some small retailers who did not deal with tar or pitch at all had been redeeming bills and it decided to prohibit this practice. ${ }^{70}$ In June of the same year, a new reply from the Regency was published after heated debate. This time it concerned bank notes. ${ }^{71}$ The Regency decreed that the tar company could not receive any bank notes or credit of any other kind at all. As to the complaint concerning excessive tar production, the Regency gave the company permission to produce pitch from 2000 mers of tar yearly. ${ }^{72}$

During the summer of 1662 , measures were implemented to achieve balanced finances within the company. However, many of the shareholders of the previous tar company were no longer interested in being involved in the reformed company. In particular, many of the wealthiest shareholders were missing. This caused difficulties in raising capital and in coping with payment to tar producers. The proposed solution to this problem was a financial agreement with Dutch company Gangel \& Deutz. Under this agreement, Dutch agents in Amsterdam paid the tar company's agents in advance so that they were able to buy salt and other necessary

\footnotetext{
${ }^{69}$ Fyhrvall, Svenska Handelslagstiftningens historia, 56; Stiernman, Samling utaf Kong. Bref, Stadgar och förordningar ungående Sweriges Rikes commerce, politie och oeconomie, vol 3, 160.

${ }^{70}$ Stiernman 1753, Resolution för Tiäru Compagniet 1662, 60-63.

${ }^{71}$ In Swedish "Banco sedlar": in the 1660's the bank of Stockholm began to distribute bank notes against the currency deposited at the bank. This was revolutionary. However, due to a lack of experience, too many notes were distributed, which apparently caused great troubles for the bank. Lappalainen, Maailman painavin raha; kirjoituksia 1600-luvun Pohjolasta, 100-101.

${ }^{72}$ Stiernman 1753, Resolution för Tï̈ru Compagniet 1662, 75-76.
} 
products from Amsterdam and ship them to Vyborg. This practice became the company's primary operating principle. $^{73}$

Despite the changes, trade in Amsterdam failed to operate smoothly. The quality of tar was the next concern. Consequently, at the end of 1662 the Regency published a new document containing a reminder that tar barrels must be full and the quality of the tar of a better standard. ${ }^{74}$ Furthermore, in April 1663, the problem of overproduction of tar resurfaced. ${ }^{75}$

The fact that Sweden had to trade with other European countries made it highly dependent on the political affairs of other nations. In May 1665, England and the Netherlands headed into war, which further worsened the tar company's weak financial situation. In the preceding winter, the tar company with its shareholders had approached both the Royal Regency and the Commercial Collegium to apply for financial support. The Regency and the College failed to reach a consensus regarding the difficulties. The College, for instance, proposed that the southern parts of Sweden should fall within the tar company's remit: however, the Regency disagreed. The solution was to raise customs duties on the purchase of tar to two dalers per mer. ${ }^{76}$

On 28 May 1665, the official decision on the company's petition was announced in Stockholm. The decision included, besides the abovementioned points, regulations regarding the practices of the tar trade. These familiar matters were handled in eight paragraphs. The first paragraph included a rule on regulation of producing tar: tar officers in the countryside, where tar was produced, were obliged to report all the tar produced. They also needed to ensure that the correct sums were entered into land registers. ${ }^{77}$ The next paragraphs abandoned the extensive use of forests. The fourth paragraph stated that the company's obligation to buy tar would be cut by one-third compared to the previous year. The fifth paragraph stated that the southern parts of the country would remain outside the company's remit, but those areas were to pay higher customs duties: two dalers per mer. The last paragraph announced a new fixed price per mer. ${ }^{78}$ In addition, the company was no longer obliged to

\footnotetext{
${ }^{73}$ Hallberg, Tjärexport och tjärhandelskompanier, 116-117.

${ }^{74}$ Stiernman 1753, Bref om Tiäru tilwärkningen 1662, 129.

75 Stiernman 1753, Resolution för Tiäru-Compagniet 1663, 160-161 and Brev om Tiäru tilwärkningen 1663, $162-163$.

${ }^{76}$ Hallberg Tjärexport och tjärhandelskompanier, 118; Stiernman 1753, Resolution för Tiäru-compagniet 1665, 333336.

${ }^{77}$ Later, on the basis of these records it was possible to examine how much tar was produced and in which parts of the country. This was also seen as an equitable way to share primary production between the peasants.

78 The new price was determined to be no more than 10 copper daler or marks or one silver daler.
} 
buy tar produced before 1659. This was justified, as the problems with the older tar would have been insurmountable. $^{79}$

In summary, the difficulties the reformed tar company faced during 1660-1665 were fundamental. The Finnish peasantry was accustomed to producing tar and thus generating extra income. Because of this, the decrease in tar production was extremely challenging, and no one was inclined to stop production of tar voluntarily. Finally, the Regency gave up its efforts and set an upper limit on the amount of tar that the company was obliged to buy.

\section{A New Attempt with the Ordinance of 1666}

Unsurprisingly, difficulties remained. An inconvenient problem faced by Sweden was stagnant trade with the Netherlands because of the second Anglo-Dutch war. The Regency and the Commercial Collegium had clearly failed to anticipate that production would once again exceed demand. The Regency began desperately to prescribe new ordinances, including several in one year, which indicated the extent of the problem. These ordinances imposed several limitations on handling currency. Borrowing money was possible only with certain written bills used outside Sweden. However, the use of bank notes was also prohibited except for selling on credit. Nearly all actions and regulations introduced by the Regency and College were guided by a chronic shortage of money. By any standards, the tar company was not on a stable development course, and the situation could not be remedied simply by new regulations..$^{80}$

In 1666, the company's debt had reached 90000 dalers. After two years, its foreign creditors also began to request payments with high interest. In order to ensure the company's survival, it was essential that new negotiations concerning the company's regulations should begin in that same year. This time the focus was administration, which encouraged the directors to participate in the discussions. The management of the company needed to be restructured. The primary proposal was that shareholders would elect three directors among themselves: one legal expert, one expert in foreign and one in domestic trade. A board, or more likely

\footnotetext{
${ }^{79}$ Stiernman, Resolution för Tiäru compagniet 1665, 333-336 and 354-355.

${ }^{80}$ Fyhrvall, Svenska Handelslagstiftningens historia, Tjärhandelskompanierna, 59.
} 
delegation, was nominated with sixteen members, whose task it was to guide the directors with their decisions. ${ }^{81}$

In fact, the shareholders thus had more influence than ever before. Their task was also to nominate the company's agents outside Sweden and in Turku, Helsinki and Vyborg. Shareholders who invested 500 dalers or more had the right to request personally from the company's office information concerning the company's businesses. If discrepancies were found, the shareholders could then report them to the company's assistant, who then informed the director. Company meetings were held whenever needed. The influence of each shareholder at their meetings was proportionate to the amount they had invested. For example, an investment of one thousand dalers was equal to one vote. ${ }^{82}$

Nevertheless, the tar company's troubles continued to increase. Its financial difficulties were obvious, and repayment of loans was a burden. Some relief was found when in March 1667 the Regency issued a decision concerning an extended privilege. The privilege included the right to sell tar outside the company, and was granted to a small number of merchants favoured by the Regency. The intention was to stimulate the tar trade with the assistance of some influential figures. This was actually partly successful. However, no far-reaching effects were achieved. Agents in Hamburg, Lubeck and Amsterdam still reported low sales volumes. ${ }^{83}$

The tar company's struggles were thus far from over. In 1668, the burghers sent a letter of complaint to the Regency, whose answer was published in October in Stockholm. It included paragraphs considering previously familiar issues such as use of equal measurements, money transactions and storage of $\operatorname{tar}^{84}$

Discontent with the tar trade and the company's operations appeared to be endless. In 1670, several complaints arose from East Bothnian peasants and city burghers. The main issues concerned customs duties and overproduction. Moreover, the peasants were dissatisfied with how barrels of tar were measured. After several complaints of this nature the Royal Regency prepared a statement reversing its previous principle: The Commercial Collegium should henceforth address these sorts of complaints instead of the king. During July 1670, the Regency once again published new regulations. This time it concerned the measurement of a barrel

\footnotetext{
${ }^{81}$ Palmsk.samlingar, a document dated 1.10.1666, RAS; Fyhrvall, Svenska Handelslagstiftningens historia, 59.

${ }^{82}$ Palmsk.samlingar, a document dated 1.10.1666, RAS.

${ }^{83}$ Document dated 19.3.1667, Ämnessamlingar, Handel och sjöfart, vol. 12, RAS.

${ }^{84}$ Stiernman, Resolution för Tiäru-Compagniet 1668, 713-716.
} 
of tar. ${ }^{85}$ In conclusion, the Regency emphasized that the company still retained a monopoly over the trade in tar. This meant that neither members of the Admiralty, nor Stockholm merchants nor anyone else had permission to trade tar without a licence from the company.

As could be foreseen, the reforms and the company's difficulties represented an insurmountable challenge. The company's creditors also pressed for repayment even though the company had no funds. Discussions about the company's dissolution and a new privilege began in 1671 and were met with strong opposition among burghers and the Commercial Collegium. After lengthy negotiations, the company's directors and shareholders decided that two-thirds of the company's capital would be removed and new shareholders would be sought to invest a total of 200000 silver coins. This was designed to launch the company on a new economic path; however, this failed to produce the desired effect. ${ }^{86}$ Instead, the burghers, who had resisted the existence of the company, finally managed to convince the Regency of the impudence and interference of the company's directors. The Commercial Collegium was thus obliged to organize investigations and a committee was established for this purpose. ${ }^{87}$

The committee concluded its report in 1671, finding that the directors were guilty of several offences and derelictions. Because the tar trade was in crisis and liberation of the tar trade was loudly demanded, the committee was obliged to elaborate a proposal for a new privilege. ${ }^{88}$

\section{The Reorganized Tar Trade and the New Privilege of 1672}

During 1672 Sweden experienced several changes, both internally and externally. In March, war broke out between France and the Netherlands, and Sweden intervened in this conflict by siding with France and offering troops for the southern coast of the Baltic Sea. For Sweden, with its financial problems, this decision was easy, as it received payments against the troops given to France. As a result Sweden participated in the war between

\footnotetext{
${ }^{85}$ The new measure would be 48 canfuls of tar instead of the earlier 54 canfuls. With the help of county governors, the overproduction of tar should have been controllable. This was necessary not only because of the reselling problems of burghers, but also because of overuse of the forests. In a clear order to the tar company, the Regency determined that the new measure of one mer was 13 tar barrels instead the previous 12 .

${ }^{86}$ Document dated 5.9.1671, Ämnessamlingar, Handel och sjöfart, vol. 12, RAS.

87 Stiernman 1753, Resolution för Tiäru-Compagniet 1670, 815.

88 Tiäru compagniet 1648-1660, Ämnessamlingar, Handel och sjöfart, vol. 12, RAS.
} 
1673 and $1674 .{ }^{89}$ Furthermore the internal political balance in Sweden changed after King Carl XI turned 18 and was crowned the lawful ruler. Prior to that, the Chancellor of Sweden, Magnus De la Gardie, had been the most powerful person in the Royal Regency. Although the situation did not immediately change, the new King began withdrawing from the previous administration, first in regard to Swedish internal policy. Nevertheless, in 1672 the young King did not interfere in the tar trade. However soon the evidence against the tar company was clear: The company's debts were high and its directors unreliable. However, the burghers' appeal to totally liberalize the tar trade was too risky a proposal. Fear of foreigners seizing the entire Swedish tar trade was rife. Consequently, a new privilege was announced on 23 July $1672 .{ }^{90}$

At the same time, the entire tar company was replaced by a new "reorganised tar company". However, the new ten-year privilege differed little from the previous one. Some of the most important shareholders were the same, such as the Stockholm Magistrate Mårten Bunge, the merchant Klas Wilkens and chamber council member Barthold Ruuth. The new reorganized company began on a totally new economic basis. The previous company's loans, tar stocks and property were not considered the new company's responsibility. Consequently, the new company was entirely separated from the previous company, in contrast to the preceding privilege of 1661. A two-year period of transition was introduced..$^{91}$ During this time, the old company could sell their old tar while the new company could not sell anything. However, the new company already had the obligation to buy certain amounts of tar from local merchants. The most notable reform concerned the obligation to buy tar. The company's trading partner remained Deutz in Amsterdam. ${ }^{92}$

As usual, the new privilege determined sales prices, but this time it was unnecessary for the payment to be in cash. Instead, payments could be made in items whose worth was counted in monetary units of three and a half copper coins. The practice of fixed prices and amounts of tar was also retained. ${ }^{93}$ A new phenomenon, however, was the $11^{\text {th }}$ paragraph of the privilege and its mention of possible complaints. The suggested practices as to

\footnotetext{
${ }^{89}$ Kirby, Northern Europe in the Early Modern Period, 295-297.

${ }^{90}$ Stiernman 1753, Privilegium för Tiäru-Comp. 1672, 950-952; Israel, The Dutch Republic, Its Rise, Greatness and Fall 1477-1806, 796-797; Kari Tarkiainen, Kustaa Vaasasta Ruotsin ajan loppuun; Kaarle IX. Article in Suomen hallitsijat. (Porvoo: Weiling+Göös, 2000), 168-171.

${ }^{91}$ This included years 1672 and 1673.

${ }^{92}$ Stiernman, Privilegium för Tiäru-Comp. 1672, 950-952.

${ }^{93}$ For example, in Vyborg the annual amount of the tar for the city was 3000 mers. The price per mer was 56 copper dalers, which had to be paid immediately.
} 
investigating and handling complaints were comprehensively explained. In general, regarding the new privilege, the King intervened in company affairs less than earlier. Moreover, the company's operations no longer needed to be based on the interests of the Crown, which also represented a change from the previous privilege. ${ }^{94}$

However, the existence of the company was on an uncertain footing for many reasons. The ongoing war did not facilitate the tar trade with the Netherlands, as Sweden was allied with France - the Netherlands' enemy. Instead, the export of tar to England and France increased considerably.$^{95}$ The first official move towards dissolving the company came in March 1773, during a parliamentary session. The reasons behind the proposal, initiated by the burghers, were familiar: the tar trade should be liberalized and the monopoly broken up, as it was too demanding to maintain trade connections with the Netherlands. In 1676, the King granted a new privilege on the grounds of the uncertain times. Even during wartime, some exceptions to the company's monopoly existed because of the urgent need for salt. This increased the pressure for the company's dissolution, which finally led to the liberation of the tar trade. ${ }^{96}$

\section{The Final Attempt to Control the Tar Trade with a Company-Model 1689-1712}

The period between 1648 and 1676 brought remarkable changes including changes to the conditions of trade - and the idea of free trade began to dominate during the reign of King Carl XI. The previous Royal Regency had failed to meet its economic targets, which also raised the need for change. In addition, the "Great Land Reduction"97 was launched which transferred political power from the nobility back to the monarch. Moreover, wealthy merchants lost control over minor burghers. During the 1670s and 1680s, calls for the company's dissolution accelerated, and finally, in 1682, an agreement was reached on free trade. Nevertheless, the return of a free tar trade after 35 years did not proceed smoothly. Previous routines had become ingrained and, but

\footnotetext{
${ }^{94}$ Stiernman, Privilegium för Tiäru-Comp. 1672, 952-955.

${ }^{95}$ Hallberg, Tjärexport och tjärhandelskompanier, 123.

${ }^{96}$ Anders Anton von Stiernman (ed.), Samling utaf Kong. Bref, Stadgar och förordningar ungående Sweriges Rikes commerce, politie och oeconomie, vol. 4, (Stockholm: Trykeriet, 1760), 13 and 16-17; Hallberg, Tjärexport och tjärhandelskompanier, 127; Fyhrvall 1880, 68-73.

${ }^{97}$ In the Great Reduction of 1680, the Swedish Crown recovered lands earlier granted to the nobility. This was accomplished during the reign of Carl XI and in practice the nobility lost its power to the Crown, Heikki Ylikangas, Käännekohdat Suomen historiassa, (Porvoo: WSOY, 1986), 67-69; Michael Roberts, The Swedish Imperial Experience 1560-1718, (Cambridge: University Press, 1979), 7.
} 
also the era was challenging: prices were low and burghers had neither the capital nor the ships to trade. Dutch merchants stopped sailing to Vyborg. Instead, Vyborg merchants had to sail to Amsterdam and pay high customs duties. In Stockholm, the local burghers were also in trouble, as the Dutch and English had taken over the local tar trade. It was necessary to improve the legislation once again..$^{98}$

In January 1682, during peace negotiations in Nijmegen, dissolution documents for the company were signed. The new ordinance took effect in October the same year. This liberated the tar trade, but it nevertheless still set customs duties, which were protested strongly by the burghers. ${ }^{99}$

As a consequence of sluggish economic progress, reorganization of the monopoly was reconsidered. Previously, the word "company" had been used to denote a corporation which traded tar under a certain privilege and enjoyed a kind of monopoly in its own field. At this time, however, the character of such corporations changed, and instead of "company" the word "society" was more often used. Societies did not enjoy the same kind of monopoly as companies. Actually, the model was closer to that of a joint-stock company or cooperative. ${ }^{100}$

In July 1689, a new privilege was issued, which covered a larger portion of the territory of Sweden than the former privileges. However, the new privilege was partly based on the privilege of 1654, and historian Oscar Fyhrvall subsequently characterized the new era as a 26-year "industry of tar slavery". ${ }^{101}$ The position of Sweden as a superpower in the Baltic Sea area was also consolidated around 1689. Therefore, the state once more assumed stricter control of the tar trade. The privilege eventually came to cover the whole of Sweden, except the island of Gotland. ${ }^{102}$

Shortly after the privilege was published, the Netherlands expressed its discontent. With the assistance of the Dutch ambassador, van Haarem, the Netherlands formulated a complaint in which it accused Sweden of breach of contract. The newly established monopoly was at the centre of these accusations. From Sweden's perspective, its actions were justified, as the name of the new entity was the tar society instead of the tar

\footnotetext{
${ }^{98}$ Fyhrvall, Svenska Handelslagstiftningens historia, 73. Stiernman 1766, Samling utaf Kong. Bref, 83. Israel, Dutch Primacy in World Trade, 1585-1740, 300-304.

${ }^{99}$ Stiernman 1760, Resol. för Tiäru. Compagniet. 1682, 483-485.

${ }^{100}$ Stiernman 1760, Öppit brefför Tiäru-Compagniet 1689, 78-79 ja 81.

${ }^{101}$ Fyhrvall, Svenska Handelslagstiftningens historia, 84-92.

102 Stiernman 1760, Öppet Bref för Tiäru-Compagniet 1689, 78-83.
} 
company, which clearly indicated that this was not a question of a monopoly. However, these semantics failed to calm the Dutch. ${ }^{103}$ The tar society, however, enjoyed a wider trading area than the previous tar company. For the first time, it exercised control of the domestic tar trade, as its privilege covered the whole of Sweden. Nevertheless, the society faced the same general problems as earlier. For instance, production continued to exceed export demand, which forced control of the trade through customs duties. ${ }^{104}$

In January 1697, the society's four-year contract was coming to an end and the King signed a letter directed to the Commercial Collegium covering 24 specific articles concerning the society's practical operations, mainly involving amounts of tar, old tar, the responsibilities of the Commercial Collegium, smuggling or other kinds of cheating, and payments. The articles did not refer to the society's internal actions, but prescribed rules for the society's functioning with other actors, which demonstrates that the society's internal decisions were made without the King's influence. Subsequently, the privileges became contracts between the Crown and the society. ${ }^{105}$

In summer 1697, the King's Chancellery signed an official contract with the society over the trade in tar. Henceforth, the society's role was more like that of an agent steering trade between producers and foreign merchants. The main reason for this change was the realization that the old system enabled smuggling between cities. The rules regarding the rights of directors and shareholders were similar to those in 1698 . The contract also had a set duration: in the society's case, four years. ${ }^{106}$ Consequently, a new contract was signed in 1702 in Bielewitz, Poland, during the Great Northern war. The content was nevertheless similar to that of the earlier contract. ${ }^{107}$

The tar society was dissolved in 1712 during the Great Northern War. Sweden maintained high tar prices. The English, in particularly, had begun to produce their own tar in their new colonies, mostly in North America. ${ }^{108}$

\footnotetext{
${ }^{103}$ Privilegibrevet, Ämnessamlingar, Handel och sjöfart, no. 78 , RAS; Stiernman 1760, Öpet brefför TiäruCompagniet 1689, 78.

${ }^{104}$ Stiernman, Bref om Tullen på Träwärcke 1689, 84-85.

105 Stiernman, Bref om Tiäruhandelen 1697, 631-635.

106 Stiernman, Contract om Tiäruhandelen 1697, 660-668.

${ }^{107}$ Stiernman, Contract med Interessenterne uti Tjäruhandelen 1702, 899-909.

${ }^{108}$ Waris, Tervakauppakomppania vuosina 1648-1661, 117.
} 


\section{Conclusions}

The tar company existed in multiple forms for 64 years. In contrast to Dutch or English companies, the central idea of the tar company was based on trade in one sales article. Conversely, the operating principle of Dutch and English companies was to dominate trade in certain geographical areas and became the major source of public finance. ${ }^{109}$ Partly for these reasons, the tar company represents an early model of a company which was hopelessly dysfunctional. The company's own directors could not entirely define the company's internal rules, because the Crown set most of these. Moreover, Sweden had little experience of companies, and when the tar company was founded in 1648 , it disrupted existing commercial activities. The privilege artificially created a new supply chain: peasant producers could sell tar only to city burghers, and city burghers could sell tar only to company agents in their own home cities. This trading path was also controlled by fixed prices and fixed sales volumes. As a result, the unfettered freedom to practice one's own occupation was destroyed.

During the first decades of its existence, the tar company provoked an exceptional number of complaints from producers as well as local and Dutch merchants; moreover, the structure of the company continually changed as it was dissolved and re-established. The Swedish Commercial Collegium attempted to address these complaints by introducing regulations that are more democratic. Unfortunately, the conflict between the merchants in the cities and the Swedish Crown made smooth operation of the company impossible. A monopoly was granted and revoked several times after 1648: in 1660, 1672, 1682 and 1689. The last company - or, to be precise, society - no longer enjoyed a monopoly position. It had moved a few steps closer to becoming a joint stock company as we understand the term today.

How did the company's "articles of association", its privileges, improve over the decades? The first tar company was granted a tar privilege for twenty years, and it was run by four directors, who also constituted the majority of its main investors. An eight-member board comprising minor shareholders, called assistants, formally represented individual shareholders. Their role was solely to conduct inspections and offer advice to the directors; their power was extremely limited. This pattern of management caused numerous complaints,

\footnotetext{
109 Janet McLean, "The Transnational Corporation in History: Lessons for Today?" in Indiana Law Journal, vol. 79, 2 , Article 2 (2004) 365. Available at: http://www.repository.law.indiana.edu/ilj/vol79/iss2/2
} 
because of which the new statute of 1654 increased the number of investors and made the leadership more democratic. The next privilege, in 1660, did not interfere in the management of the company except to specify the amount shareholders were required to invest.

However, the 1666 instruction profoundly altered the management structure. Now there were to be three directors with specific fields, and their tenure was of fixed duration. The board had 16 members with a consulting role. The privilege of 1672 included no new articles on the management. However, in 1689, the management structure was rearranged yet again. Two of the four directors were replaced every third year. Shareholders with investments of 1000 dalers exercised one vote. Those with smaller investments could gather together to share one vote. These management changes illustrated the progress from the early stages of the company. However, they probably developed from the needs of the king instead of from internal needs.

Furthermore, the Crown micromanaged control of sales at every level, using the privileges. Moreover, from the very first privilege, the amounts of tar traded and the size of the barrels were strictly controlled, as were the purchase and resale prices and customs duties. Sweden's mercantilist commercial policy ultimately proved unsustainable. Gradually, the structure of supervision evolved, as can be observed in the legislation. In 1689, there was still mention of customs duties and amounts of tar, but its character had altered. They were no longer the king's sole focus. Tar regulation had become more diverse and the scope had expanded.

Eventually, the most significant and powerful of the privileges concerned both currency and control of debts and loans. The year 1661 saw the beginning of a new phase, when the Commercial Collegium was given the main responsibility for the tar company. Sweden was heading for major financial difficulties, and economic policy required a dedicated College focused on one issue. By issuing orders concerning payments, the College governed the company's financial resources. It made mistakes and experienced failures, but was nevertheless able to maintain a tolerable balance in Sweden's financial affairs. The company evolved from being the company of a monarch to something closer to a state-owned company.

Interpreting mercantilist ideology creates challenges for historians. How can trade be separated from state and government, and is it even possible or necessary? Essentially, the state formulated the statutes which created the company's operational framework. In a sense, this meant that the state or monarch exercised full control. 
But did this make the tar companies state-owned companies? To answer this question requires a discussion of the differences and similarities between the concept of nation and business. In the seventeenth century, Swedish trading was highly polarized, with controlled trade in the cities and less regulated trade between peasants in the countryside. The cities could be described as outwardly regulated by the monarchy, but still part of regulated society. The lower level of the cities comprised its inhabitants, the citizens, who obeyed the rules imposed by the monarch. This tempted rulers to supervise trade through control of the cities. Nevertheless, the problem with the pattern was the citizens themselves, who were not steerable like machines. Instead, they wished to satisfy their own desires. This separates the state from trade, as the citizens rather than the government conducted trade. The tar company was designed to control these agents: peasants, traders, foreign buyers, and investors. However, it was doomed to failure. Still, the saga of the company was essential for further development.

The legal character of the tar company also exemplified changes in ideas and influences, which came from many directions. The Netherlands, England and France all affected it to some degree. Moreover, Sweden was in turn ruled by the Crown or the Royal Regency, which had opposing interests. The Regency was an arena for competing high nobility, whereas the King or Queen exercised absolute power, depending of course on their personality. The legal character of the Companies thus could not develop steadily. Rather, evolution occurred in sudden leaps and sometimes movement was even backwards. This development was fettered by constant complaints, slow tar markets, Sweden's relations with foreign powers, and by changes in mercantilist ideology. However, the apparent trigger for evolution of the legal character of the tar company was the numerous cancellations of privileges. These provided necessary pauses for new regulations to mature, and the new privilege was always able to learn something from its predecessors. After trial and error, a more serene era began when the tar trade was opened and liberalized.

Unprinted Sources:

Riksarkivet Stockholm (RAS), Ämnessamlingar, Handel och sjöfart, no. 12, no. 63. 
Source editions:

Stiernman, And. Anton von (ed.), Samling utaf kongl. Bref, stadgar och forordningar angaende Sweriges Rikes commerce, politie och oeconomie, vol. 1 (Stockholm: Kong. Tryckeriet, 1747).

Stiernman, And. Anton von (ed.), Sweriges Rikes commerce. politie och oeconomie uti gemen uppå Hans Kongl.Maj:ts nodigsta belfallning, vol 2. (Stockholm: Kong. trykeriet, 1750).

Stiernman, And. Anton von (ed.), Samling utaf Kong. Bref, Stadgar och förordningar angående Sweriges Rikes commerce, politie och oeconomie, vol. 3, (Stockholm: Tryckeriet, 1753).

Stiernman, Anders Anton von (ed.), Samling utaf Kong. Bref, Stadgar och förordningar ungående Sweriges Rikes commerce, politie och oeconomie, vol. 4, (Stockholm: Trykeriet, 1760).

Literature:

Aalto, Seppo, "Helsinki, tervakaupunki" in (eds.) Jensen-Eriksen, Niklas - Lappalainen, Mirkka Nurmiainen, Jouko - Siltala, Sakari, Kansallinen kapitalismi, kansainvälinen talous (Helsinki: Siltala, 2012).

Amend-Traut, Anja, Legal Structure of Early Enterprises - from Commenda-like Arrangements to Chartered Joint-Stock Companies, in (eds.) De ruysscher et al., The Company in Law and Practice: Did Size Matter? (Middle Ages-Nineteenth Century) (Leiden: Brill, 2017).

Björnsson, Anders \& Magnusson, Lars (eds), Jordpäron, Svensk ekonomihistorisk läsebok (Stockholm: Bokförlaget Atlantis, 2011).

Fyhrvall, Karl Oskar, Svenska Handelslagstiftningens historia, Tjärhandelskompanierna (Stockholm 1880).

Gardberg, C. J., Kaupunkilaitos keskiajalla ja uuden ajan alussa in (eds.) Gardberg, C. J. - Tommila, Päiviö Endén, Rauno, Suomen kaupunkilaitoksen historia (Vantaa: Suomen kaupunkiliitto, 1981).

Gephen-Jager, Ella - Soling, Gerard van and Timmerman, Levinus (eds.), VOC 1602-2002; 400 Years of Company Law (Dordrecht: Kluwer, 2005).

Hallberg, Annagreta, Tjärexport och tjärhandelskompanier, in Steinby, Torsten (ed.) Historiska och litteraturhistoriska studier no 34, (Helsinki: Svenska litteratursällskapet i Finland, 1959).

Heckscher, Eli F: An Economic History of Sweden (Cambridge: Harvard University, 1954), 73. Raimo Ranta, Turun kaupungin historia 1600-1721, (Turku: 1975).

Heckscher, Eli, Merkantilismen (Stockholm: P. A. Norstedt \& Söners Förlag, 1953).

Hofstraeten, Bram van, Delving for Diversity in Early Modern Company Law: Mining Companies in Seventeenth-Century Liège, in (eds.) De ruysscher et al., The Company in Law and Practice: Did Size Matter? (Middle Ages-Nineteenth Century) (Leiden: Brill, 2017).

Israel, Jonathan I., Dutch Primacy in World Trade, 1585-1740 (Oxford: Clarendon Press, 1989).

Israel, Jonathan, The Dutch Republic, Its Rise, Greatness and Fall 1477-1806 (Oxford: Clarendon Press, 1995),

Kirby, David, Northern Europe in the Early Modern Period; The Baltic World 1492-1772 (London: Longman, 1990). 
Kirby, David and Hinkkanen, Merja-Liisa, The Baltic and the North Seas (London - New York: Routledge, 2000).

Klein, Peter Wolfgang, 'A New Look at an Old Subject: Dutch Trade Policies in the Age of Mercantilism', in (eds.) Groenveld, Simon \& Wintle, Michael, State and Trade, Government and the Economy in Britain and the Netherlands since the Middle Ages (Zutphen: Walburg Press, 1992).

Korpiola, Mia \& Ojala-Fulwood, Maija, Controlling Immigrants in Sweden, ca. 1520-1620: Norms, Regulation, and Legal Practice in (eds.) Anette Baumann, Alexander Jendorff \& Frank Theisen, Religion Migration - Integration. Studies on the Reciprocal Effects of Religiously Motivated Mobility in Pre-Modern Europe (Tübingen: Mohrsiebeck, 2019).

Korpiola, Mia, "High and Late Medieval Scandinavia, Codified Vernacular Law and Learned Legal Influences" in (eds.) Heikki Pihlajamäki, Markus Dubber, Mark Godfrey, The Oxford Handbook of European Legal History (Oxford: Oxford University Press, 2018).

Kuisma, Markku, Metsäteollisuuden maa; Suomi, metsät ja kansainvälinen järjestelmä 1620-1920. (Helsinki: Suomalaisen kirjallisuuden seura, 2006).

Lappalainen, Mirkka, Loyal Servants of the King and the Crown (1620-1680) - Stewards and Governors in Sweden before the Age of Absolutism, in (eds.) Petri Karonen and Hakanen Marko, Personal Agency at the Swedish Age of Greatness 1560-1720 (Helsinki: The Finnish Literature Society, 2017).

Lappalainen, Mirkka, Maailman painavin raha; kirjoituksia 1600-luvun Pohjolasta (Helsinki: Werner Söderström Osakeyhtiö, 2006).

Lindkvist, Thomas \& Sjöberg, Maria, Det Svenska samhället 800-1720; Klerkernas och adelns tid (Lund: Studentlitteratur, 2010).

Nováky, György, Handelskompanier och kompanihandel; Svenska Afrikakompaniet 1649-1663, En studie i feodal handel (Uppsala; Acta Universitatis Upsaliensis, 1990).

McLean, Janet, The Transnational Corporation in History: Lessons for Today? Indiana Law Journal: vol. 79, 2, (2004).

Müller, Leos: The Merchant Houses of Stockholm, c. 1640-1800; A Comparatively Study of Early-Modern Entrepreneurial Behaviour. (Uppsala: Uppsala University Library, 1998).

Möller, Sylvi: Suomen tapulikaupunkien valtaporvaristo ja sen kaupankäyntimenetelmät 1600-luvun alkupuolella. Dissertation, University of Helsinki (Helsinki: 1954).

Odhner, Clas Theodor, Sveriges inre Historia under Drottning Christinas Förmyndare (Stockholm: P. A. Norstedt \& Söner, 1865).

Palmén, Ernst Gustaf, Historisk framställning af den svensk-finska handelslagstiftningen från Gustaf Vasas regering till 1766 (Helsinki: J. C. Frenckell \& Son, 1876).

Pihlajamäki, Heikki, "The Birth of Commercial law in Early Modern Sweden” in (eds.) Heikki Pihlajamäki, Albrecht Cordes, Serge Dauchy, Understanding the Sources of Early Modern and Modern Commercial Law: Courts, Statutes, Contracts, and Legal Scholarship. (Leiden: Brill, 2018).

Roberts, Michael, The Swedish Imperial Experience 1560-1718 (Cambridge: University Press, 1979).

Runefelt, Leif, Hushållningens dygder. Affektlära, hushållningslära och ekonomiskt tankande under svensk stormaktstid (Stockholm: Almqvist \& Wiksell International, 2001). 
Ruuth, J. W. and Halila, Aimo, Viipurin kaupungin historia 1617-1710, (Helsinki: Torkkelin säätiö, 1974).

Kari Tarkiainen, "Kustaa Vaasasta Ruotsin ajan loppuun. Kaarle IX” in Suomen hallitsijat. (Porvoo: Weiling+Göös, 2000),

Tikka, Katja, "Kauppaa ja laivoja, Komppaniatoiminnan kehityspiirteitä 1600-luvun Itämerellä" in Tapio Bergholm (ed.) Työ merellä, Nautica Fennica 2015-2016 (Helsinki: Suomen merimuseo, 2016).

Turpeinen, Oiva, Mustan kullan maa; Tervan historia, (Somero: Amanita, 2010).

Waris, Heikki, Tervakauppakomppania vuosina 1648-1661. (University of Helsinki, approx. 1940).

Wirta, Kaarle, Dark Horses of Business, Overseas Entrepreneurship in seventeenth-Century Nordic Trade in the Indian and Atlantic Oceans (PhD dissertation, Leiden University, 2018).

Ylikangas, Heikki, Käännekohdat Suomen historiassa, (Porvoo: WSOY, 1986).

Åström, Swen-Erik, From Tar to Timber. Studies in Northeast European forest exploitation and foreign trade 1660-1860 (Helsinki: The Finnish Society of Sciences and Letters, 1988). 